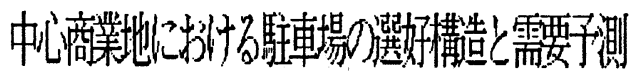

Preference Structure and Demand Forecast for Parking Lots in a Central Shopping Area

$$
\text { 長瀬恵一郎 } * \text { 中野裕成 }{ }^{* *} \text { 、松本昌二*** }
$$

By Keiichirou Nagase, Hironari Nakano, Shoji Matsumoto

\begin{abstract}
The improvement of parking lots and their management contribute to revitalizing the commercial function of an central area in a local city. First, we investigate the preference structure of users for parking lots by using the measurement techniques such as the analytical hiararchy process (AHP) and a conjoint method(CJM). A questionnaire survey was carried out against users of parking lots in the central area of Nagaoka City. Both of the measurement reveal that the distance from a parking lot to destination and parking fees are the most important factors for users. Secondly, we analize the relationship between the priority index by the AHP and the operational efficiency of parking lots to introduce a demand forecasting model for a parking lot.
\end{abstract}

1.はじめに

近年、自動車利用の伸展に伴い、特に地方都市に おいて、都心部の駐車難や道路混雑による都心商業 地の衰退と都心機能の低下が指摘され、駐車場は都 市活動を活性化、誘導するための重要な都市施設と して認識されている1〉。

駐車場整備に関わる諸問題の中で、利用者の駐車

キーワード 駐車場 階層分析法 コンジョイント 测定法

* 正会員 工修 長岡技術科学大学助教授 工学部建設系

（广940-21 長岡市上富岡町1603-1）

**工修 神戸製鋼所施設部加古川施設室

（行675-01 加古川市金沢町 1)

***正会員 工博 長岡技術科学大学教授

工学部建設系

(同上)
場選択特性の解明は、駐車場整備の指針をたてるに 当たっての大きな課題と思われる。

既往の研究のうち駐車場の選択特性に関し、主に 利用者の行動面から解析したものには、商業施設を 対象に駐車場選択に関する非集計モデルを構築し、 商業施設の選択について考察したすの ${ }^{2 y}$ 混雑度を考 慮した駐車利用均衡モデルを構築したもの 3 等があ り、一方、主に利用者の意識面から解析したすのに は、潜在変数をむとに意識構造モデルを構筑したも $の^{4}$ 駐車料金と目的施設加らの距離を分析し、徒歩 距離最小化モデルから駐車行動を表現したすの ${ }^{5}$ 駐 車場所選択行動実験の意識データから非集計モデル を構筑したものら等が報告されている。

本研究は、地方都市の中心商業地における駐車場 整備の効果を「利用者の利便性」という視点に立ち、 利用者の意識調查結果をむとに探ろうとするすので ある。

すなわち、利用者の意識調査結果から、駐車場利 用に関する詳細な意識と行動とを抽出し、駐車場整 
備との関係を分析することにより、駐車需要予測モ デルを構筑し、それによって、駐車需要の制御・誘 導や、有効な供給方法及び施設の形態等を論ずる基 盤を提供することを目的としている。

さらに、意識分析に用いる手法について、複数の 手法の比較検討す併せて行っている。

2 . 分析方法とその適用

\section{(1) 分析方法}

本研究では、駐車場利用者の駐車場選好に対する 意識構造を分析し、解明するために「一対比較デー 夕」を階層分析法 (A H P ) 、「序列データ」をコ ンジョイント測定法（C J M ）と呼ばれる分析手法 を適用する。

アンケート（駐車場に関する意識調查）によって、 駐車場選好の意識構造データを収集するが、意識構 造データは

(1)「一対比較データ」…駐車場選択の場合に考 える要因、駐車場の内容についての一対比較

(2)「序列データ」…都心部の駐車場の選択につ いての選好序列

の 2 種類のデータを得られるように、意識調查を 設定する。

上に述べた 2 つの手法による、選好意識構造の違 いや同質性の検討等も併せて行う。

\section{（2）階層分析法の適用}

\section{a) 概要}

階層分析法（以下、A H P ) は、比率尺度による 一対比較をむとに、全体としての項目間の比率尺度 を決定する手法である。

この A H P の特徵の 1 つは、要因を階層化するこ とにより、駐車場選好の重みを構造的に把握できる ことである。

また、一対比較を用いることで定性的な要因む評 価でき、さらに、新規駐車場の重みを予測する場合 には、㫮層化された要因毎に、既存のすのとの一対 比較により判断を行うため、評価基準が明確となり、 より正確な予測が行えることす特徵である。
A H P の理論や数学的背景などは、参考文献 7) に詳述されている。

ここでは、重みの計測プロセスについて示す。

b ) 重み計測プロセス

1) 第 1 段階（問題の構造化）

本来、駐車場の選好に関しての個人行動は、駐車 場の構造、立地位置等の整備条件、料金・案内等の 運営条件、さらには違法駐車取締等の周辺路上駐車 に関する条件に左右される。

また、最終的な駐車場選好に至る意識的経過は、 駐車場をめぐる種々の要因間の比較を経て到達する。

どのような要因があるかについては、既往研究か らす類推可能であるが、本研究においては、被験者 が路上駐車という選択をせず、複数の一時預かり駐 車場のうち、どれを選ぶかという観点から、問題の 構造化を行った。

本研究においては、最上層（第 1 層）に位置する 総合目的は、当然駐車場の選好である。

以下、評価基準となる駐車場の選好を評価する要 因を第 2 層として、階層図を構成する。

駐車場の選好を評価する要因として、まず、2 層 目のレベルにおいては、(1)利便性、(2)操作性、(3)経 済性の 3 要因を設定する。

次に、3 層目のレベルにおいては、 2 層目での要 因を配慮して、(1)目的地までの距離、(2)駐車待ち時 間、(3)駐車場の形態（駐車のしやすさ）、(4)誘導標 識の有無、(5) 1 時間当たりの駐車料金、(6)買物割引 の有無の 6 要因を設定する。

一般にA H Pにおいては、最下層には（今回の場 合 4 層目) 代替案そのあのを設定するが、本研究に おいては、数多くの分析対象物（選択対象の駐車場） を扱いたいために、一つ上のレベルの第 3 層の 6 要 因について各々水準を変化させたすのを、各々の評 価要素とする。

これによって、要因の水準から分析対象物への変 換が可能となる。

また、ここでの要因の水準は、後に述べる C J M での要因の水準との整合性を考慮している。

以上により構築された、A H Pによる意志決定の ための階層図 (階層構造) を図一 1 に示す。 


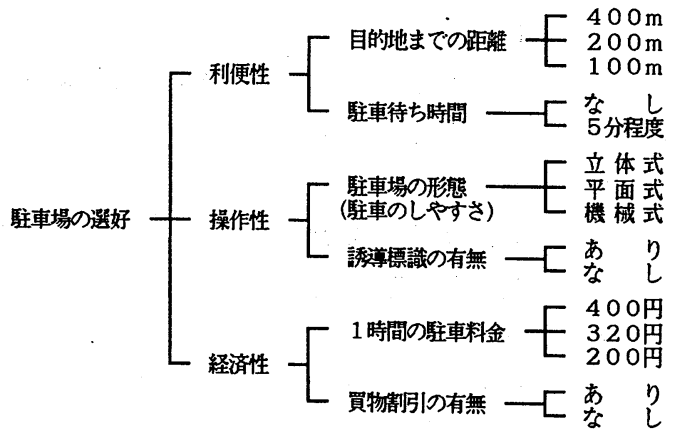

図-1 階風図 (階層構造)

2 ）第 2 段階（評価要因の一対比較）

ここでは、各レベルの要素間の重み付けを行う。

図ー 2 が、実際のアンケート票における一対比較 の設問の一部である。

左右2つのものを政してでちちらをどのくらい重視しますか」または 「どちらをどのくらい好々穼すか」という算問があります。

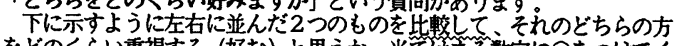
をどのくらい重視する（好む）と思うか、当て经まる数字に○をつけてく ださい。(数字の意味は下記に示すとおりです。)

\begin{tabular}{|c|c|c|c|}
\hline 1 & 利 便 性 & 432101234 & 操 作 性 \\
\hline & 操 作 性 & 432101234 & 経済性 \\
\hline & 経 済 性 & 432101234 & 利：便性 \\
\hline
\end{tabular}

(数字の意味)

\begin{tabular}{|ll|}
\hline 0 & 同し位 重視 \\
1 & 若干 重視 \\
2 & 重視 \\
3 & 咕り重視 \\
4 & 絶奶的に 重視 \\
\hline
\end{tabular}

図-2 一対比較アンケートの一例

$\mathrm{n}$ を比較要素数とすると、意志決定者は、 $\mathrm{n}_{2}$ す なわちn(n-1)/2個の一対比較をすることになる。

ある一つのレベルにおける要素間の一対比較は、 一つ上のレベルの関係要素をさらに細分化し、評価 基準として行うことになるが、最下層である 4 層目 については、3 層目の要因の水準を変化させたすの について一対比較を行っている。

このことにより、各水準毎に得られる值は、それ ぞれの水準に想定される効用值に相当すると考えら れる。

以上のようにして得られた各レベルの一対比較マ トリックス（既知）から、各要素間の重み（未知） を計算する。

これには、線形代数の固有值の考え方を用いる。
（3）コンジョイント測定法の適用

コンジョイント测定法（以下、C J M) は、序列 データに対してその序列を再現するように、各属性 の重み (パラメータ) を推定するあのである。

C J M の理論等については、参考文献》10〉11) に 詳述されている。

ここでは、C J Mにおける序列データの一般的な 収集方法について示す。

収集方法は、以下の手順によることが多い。

(1) 属性を複数の水準に設定する。

(2) 実験計画法の直交配置を用いて選択肢を編成 する。

（3）選択肢を被験者に提示し、序列データを得る。

この手順に従って、選択肢を設定し、データの収 集を行う。

駐車場選好データは、実験計画法に基づく仮想的 選択肢であるため、全ての選択肢に序列をつけるこ とが可能である。

一般的に序列付けされた選択肢数が多いほど、個 人の情報量が增え、モデルにおけるパラメータが安 定する傾向にあるが、過度の順位付けを強要すると 特に下位の序列は、上位の序列に比較してデータの 信頼性が劣り、その結果としてモデル全体の精度を 下げることがある。

既存研究 ${ }^{12)}$ においては、その選択肢数が 4 から 7 の間ではモデルのパラメータ間に有意な差は認めら れず、選択肢数が 8 以上になるとパラメータの違い が明らかになることから、選択肢数は 7 程度が限度 と報告されている。

本研究においては、A H P との比較検討す行おう としているため、選択肢数を A H P において設定し た 6 要因に合わせ、 6 とすることす考えられるが、 適切な選択肢数の上限 7 程度に近いこと及び選択肢 数 4 で解析可能という知見を踏まえ、本研究では、 選択肢を距離・料金・形態・待ち時間という基本的 な 4 要因として、表一 1 に示す 9 箇所の駐車場から 選択したい駐車場を第 4 位まで選んですらうことに より、序列データの収集を行うこととした。 
表一 1 避択肢一筧表

\begin{tabular}{|c|c|c|c|c|}
\hline$\searrow$ & 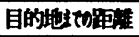 & 敦車場の形悲 & 侱車科金(時间) & 住車待ち時间 \\
\hline $\mathbf{A}$ & $200 \mathrm{~m}$ & 立体式駐車場 & $200 \mathrm{P}$ & 5分程度 \\
\hline B & $400 \mathrm{~m}$ & 立体式醉車場 & $320 \mathrm{OP}$ & 5分程度 \\
\hline C & $200 \mathrm{~m}$ & 機械式䮦車場 & $320 \mathrm{O}$ & な $L$ \\
\hline $\mathrm{D}$ & $100 \mathrm{~m}$ & 平面式駐車場 & $320 \mathrm{P}$ & 5分程度 \\
\hline$\ddot{\mathrm{E}}$ & $100 \mathrm{~m}$ & 機械式駐車場 & $200 \mathrm{f}$ & 5分程度 \\
\hline $\mathrm{F}$ & $100 \mathrm{~m}$ & 咅体式駐車場 & $400 \mathrm{O}$ & な \\
\hline G & $400 \mathrm{~m}$ & 平面式駐車場 & $200 \mathrm{H}$ & な \\
\hline $\mathrm{H}$ & $400 \mathrm{~m}$ & 機械式駐車場 & $400 \mathrm{O}$ & 5分程度 \\
\hline I & $200 \mathrm{~m}$ & 平面式駐車場 & $400 \mathrm{P}$ & 5分程度 \\
\hline
\end{tabular}

\section{3. 実態調查}

本研究では、新渴県長岡市を対象とし、中心商業 地において、主に買物目的で来街し駐車場を利用す る人々は、どのような意識構造によって駐車場の選 好を行っているのか、また、駐車場に関してどの様 な考えを持っているのかを知るため、長岡市の中心 商業地に立地する一時預かり駐車場において、駐車 場利用者を対象にアンケートを実施した。

\section{（1）調查内容}

1) 対象地域

長岡駅周辺中心商業地

2 ) 調查対象者

対象地域内の一時預かり駐車場利用者

3 ) 調查方法

利用者に調查票を配布し、郵送回収

4 ) 調查期日

平成 3 年 11 月の日曜日 (晴天)

5 ) 調查内容

(1) 被験者の個人及び家庭の家庭の属性

（2) 都心部の駐車場の選好序列 ( C J M )

（3）駐車場の選択要因（A H P)

(4) 駐車場の内容

(5) 駐車場利用についての意見

6 ）配布及び回収状況

1000 票配布し、有効回収票数371票

（有効回収率37.1\%)

（2）被験者の属性

1 ）性別
男性 $61.5 \%$ 、女性 $38.5 \%$ となっている。

2）年噛

30 才代が $35.0 \%$ と最す多く、20〜40

才代で86.5\%と大半を占めている。

3 ) 職業

会社員が59.3\%と大半を占めている。また 女性有職者が約 $2 / 3$ 占めていた。

4) 居住地

長岡市等 1 次商圈（平成元年度新潟県広 域商圈動向調查による）が55.3\%となって いるが、他の商圏及び商圏外からあ比較 的多く来街している。

5 ) 自動車保有台数

2 台以上が $63.9 \%$ と保有台数の増加傾向を 示している。

4. 分析結果

（1）階層分析法による結果

階層分析法（A H P ）を用いて算出した評価要因 間及び評価要因の水準の重み（重要度）を表一 2 に 示す。

\begin{tabular}{|c|c|c|c|c|c|}
\hline 評価要因 & 重要度 & 評価内容 & 重要度 & 水 準 & 重要度 \\
\hline \multirow[t]{2}{*}{ 利便性 } & \multirow[t]{2}{*}{$\begin{array}{c}0.444 \\
(1.905)\end{array}$} & 目的地までの距離 & $\begin{array}{c}0.545 \\
(1.716)\end{array}$ & $\begin{array}{l}400 \mathrm{~m} \\
200 \mathrm{~m} \\
100 \mathrm{~m}\end{array}$ & $\begin{array}{l}0.060 \\
0.246 \\
0.694 \\
\end{array}$ \\
\hline & & 駐車待ち時間 & $\begin{array}{c}0.455 \\
\text { (1. } 434)\end{array}$ & な分程度 & $\begin{array}{l}0.794 \\
0.206\end{array}$ \\
\hline \multirow[t]{2}{*}{ 操作性 } & \multirow[t]{2}{*}{$\begin{array}{c}0.207 \\
(1.107)\end{array}$} & 駐車のしやすさ & $\begin{array}{c}0.739 \\
(3.347)\end{array}$ & 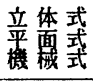 & $\begin{array}{l}0.244 \\
0.591 \\
0.165 \\
\end{array}$ \\
\hline & & 誘導標識の有無 & $\begin{array}{c}0.261 \\
(1.182)\end{array}$ & $\begin{array}{l}\text { あ } \\
\text { な }\end{array}$ & $\begin{array}{l}0.761 \\
0.239 \\
\end{array}$ \\
\hline \multirow[t]{2}{*}{ 経済性 } & \multirow[t]{2}{*}{$\begin{array}{c}0.348 \\
(1.480)\end{array}$} & 時間駐車料金 & $\begin{array}{l}0.424 \\
\text { (1. } 352)\end{array}$ & $\begin{array}{l}400 \text { 胃 } \\
32007 \\
200 \text {. }\end{array}$ & $\begin{array}{l}0.061 \\
0.189 \\
0.750\end{array}$ \\
\hline & & 買物割引の有無 & $\begin{array}{c}0.576 \\
(1.834)\end{array}$ & な & $\begin{array}{l}0.837 \\
0.163\end{array}$ \\
\hline
\end{tabular}

注：（）はt值: (平均値 /標準后差)

個人サンプル毎に求めた重みの算術平均と幾何平 均を比較したところ、ほとんど差がなかったので、 重要度は、算術平均を採用した。なお、 $\mathrm{t}$ 値は各被 験者毎の重要度の平均值／標準偏差として設定した あのである。

次に、表一 2 に示したそれぞれのレベル 3 （3層 目）の各要因の重要度に、その上のレベル 2（2 層 
目）の持っている重要度を乗じることによリ、レべ ル 3 の各要因が持つ総体的な重要度を算出した結果 を、表一 3 に示す。

表ー3 レベル 3 の相対的重要度

\begin{tabular}{|l|l|}
\hline 評 洒 内 容 & 相対的重要度 \\
\hline 目的地までの距離 & 0.242 \\
\hline 駐車待ち時間 & 0.202 \\
\hline 駐車形態 (しやすさ) & 0.153 \\
\hline 誘尊僄識の有無 & 0.054 \\
\hline 1 時間当たりの駐車料金 & 0.148 \\
\hline 買物割引の有無 & 0.200 \\
\hline
\end{tabular}

表ー 3 によれば、利便性を表す「目的地までの距 離」と「駐車待ち時間」、及び経済性に関連する 「買物割引の有無」が重要視されていることがわか る。「誘導標識の有無」は、反対に最す軽視されて いる要因である。

表一 2 の各重要度の $\mathrm{t}$ 值をみると、中には他より 值が小さく、バラッキが大きいすのす含まれている。 しかし、総体的には $\mathrm{t}$ 值はある程度の值を保持し ており、個人間のバラッキが小さいことがわかる。 表ー 2 に示した各水準の重要度をみると、例えば 「目的地までの距離」は距離の減少割合以上に重要 度が増加する傾向が読み取れる。駐車場形態による 「駐車のしやすさ」、「時間駐車料金」についてあ 同様の傾向であり、納得のできる結果が得られてい る。

（2）コンジョイント測定法による結果

駐車場選好の基本モデル、すなわち全体効用と属 性別効用（部分効用）との関係を規定するため、以 下のようなモデル式を設定し、このモデル式に基づ いて C J Mの分析を行った。

＜駐車場選好の基本モデル式 >

$$
Z_{i}=a_{j}+b_{k}+c_{1}+d_{m}
$$

$Z_{\mathrm{i}}:$ 第 $\mathrm{i}$ プロファイルの全体効用

$a_{j}$ : 「目的地までの距離」の第 $j$ 水準の部分効用

$\mathrm{b}_{k}$ : 「駐車場の形態」の第 $k$ 水準の部分効用 $c_{1}$ ：「駐車料金」の第1水準の部分効用

$\mathrm{d}_{\mathrm{m}}$ :「駐車待ち時間」の第m水準の部分効用

アンケートより個人別に得られた序列データを、 個別に C J M手法を適用することにより、各個人の 属性別効用値を測定し、それに基づいて、被験者の 理想プロファイル及び属性のパラメー夕等必要な情 報を導出した。

また、各属性の水準值（1、2、3）が大きいほ ど効用が大きくなるように選択肢を設定しているた め、求められたパラメータの符号が負になる場合に は、属性と全体効用の間に矛盾が生じる。

そこで、パラメータを推定するに際して、推定さ れたパラメータが負である場合には、その属性を削 除して、再びパラメータの推定を行うという操作を 行った。

表一 4 は、各属性のパラメータ值及びA H P 手法 と同じく各被験者毎のパラメータ值の平均值/標準 偏差として設定した $\mathrm{t}$ 值を表している。各属性のパ ラメータ值に水準値 $(1 、 2 、 3)$ を乗じたすのが 部分効用である。

表ー4 の各属性のパラメータをみると、「駐車料 金」のパラメータが 0.461 と最大であり、ついで 「目的地までの距離」が0.369であり、駐車料金と 距離を最む重視している。 $\mathrm{t}$ 值は、A H P に比べる と総体的に小さい。

しかし、パラメータ値の傾向をA H P による結果 と比較してみると、駐車料金と距離が特に重視され ていることは共通している（AHPによる「時間駐 車料金」と「買物割合の有無」を合成した「経済性」 を、C J Mによる駐車料金に対応させて比較してい る) 。

この駐車場選好モデルによって求められる最す効 用値の高い選択肢と、アンケート調查で一番目の序

表ー4 駐車場選好モデルのパラメータ

\begin{tabular}{|l|ll|}
\hline \multicolumn{1}{|c|}{ 属 } & パラメータ & ( t 值 ) \\
\hline 目的地までの距離 & 0.371 & $(0.992)$ \\
\hline 駐車場の形態（しやすさ） & 0.227 & $(0.719)$ \\
\hline 駐車料金 & 0.460 & $(1.197)$ \\
\hline 駐車待ち時間 & 0.264 & $(0.700)$ \\
\hline \hline 中 的 & \multicolumn{3}{|c|}{$90.5 \%$} \\
\hline
\end{tabular}

注 $\mathrm{t}$ 值: (平均值／標準偏差) 
列に選ばれた選択肢が一致した場合を的中として、 的中率を求めると、90.5\%となり、的中率でみる限 りでは、適合性は良いことがわかる。

\section{（3）分析方法の比較}

以上、駐車場選好の意識構造に対して、A H P と C J M の手法による評価について述べてきたが、基 本的に各手法は以下の特徵を持っている。

(1) A H P は、データの加工が必要だが、アンケ 一下調查は一対比較であるため、C J M に比べ 被験者にとって解答の労力が少ない。しかし、 評価項目が多くなると労力が増加する。

(2) C J M は、収集デー夕をそのまま分析に用い ることができるが、順位付けは、被験者にとっ て解答の労力が大きい。

そこで、本研究の A H P 適用では、評価要因のグ ループ分けを行い、1 度に一対比較を行う要素数は 最大 3 要素とした。

階層構造の各階層毎に一対比較を行ったので、計 18 回の一対比較を行ったことになる。

一方、C J M 適用では、上位 4 位までの選択肢の 順位付けを行ったが、評価要因の数を 4 個に限定し て被験者の労力を配慮した。

両手法による評価結果を比較してみると、既に述 べたように、選好結果の傾向は類似している。

しかし、両手法で同様に設定した $\mathrm{t}$ 值の違いが示 すように、個人のバラッキはA H P の方が小さく、 選択肢の順位付けよりも多くの一対比較の繰り返し による方が、信頼できる結果が得られたことになる。

5. 駐車需要予测モデル

\section{（1）駐車場利用台数予测モデルの構築}

これまでの検討により、A H P 手法によるモデル の方が信頼性や操作性で優れていたので、A H P 手 法の結果をすとに、長岡市の中心商業地を事例とし て、駐車場選好の意識構造を考慮した駐車需要予測 モデルの構筑を検討する。

まず、図一 3 に示す長岡市の中心商業地に存在す る一時預かり駐車場 20 力所について、各駐車場毎
の、目的地までの距離、駐車待ち時間、駐車のしゃ すさ、誘導標識の有無、時間駐車料金、買物割引の 有無の水準值に表-3の重要度を乗じて足し合わせ、 各駐車場の選好得点を算出する。水準値の中で「目 的地までの距離」は、中心部の代表的な大型店舗 1 1 箇所までの距離とし、各駐車場毎に目的地別の選 好得点を算出した。

さらに、各店埔の集客力の違いによる影響を勘案 するため、各店舗の店舗面積比率を各々の選好比率 に乗じて足し合わせた値を、一時預かり駐車場毎の 総合的な選好得点（以下、単に「選好得点」とする） とした。その結果を表 -5 に示す。

つぎに、各駐車場の利用台数（平成 3 年 11 月 1 ヶ月間）、駐車容量、及び選好得点との関係を分析 した（表一5）。

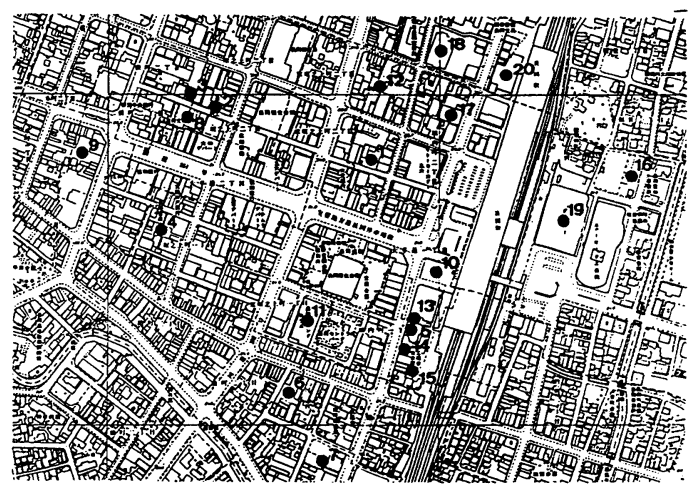

目一－長岡市内の一時预かり駐車場立地状况

表-5駐車場の利用台数. 回転率と選好得点

\begin{tabular}{|c|c|c|c|c|}
\hline 駐 車 場 名 & $\begin{array}{l}\text { 利用台数 }\end{array}$ & 臨重 & 回転率 & 選㛒 \\
\hline 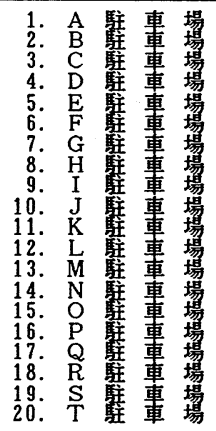 & $\begin{array}{r}3,000 \\
3,600 \\
3,000 \\
- \\
3,-700 \\
6,200 \\
5,100 \\
6,200 \\
18,000 \\
3,000 \\
7,000 \\
1,500 \\
3,300 \\
6,-100 \\
6,800 \\
17,800 \\
38,400 \\
14,200\end{array}$ & $\begin{array}{lll} & 1 & 4 \\
& 2 & 2 \\
2 & 5 \\
3 & 0 \\
3 & 1 \\
3 & 5 \\
3 & 5 \\
3 & 5 \\
3 & 8 \\
5 & 0 \\
5 & 6 \\
6 & 0 \\
6 & 0 \\
6 & 0 \\
6 & 2 \\
& 6 & 8 \\
8 & 5 \\
1 & 0 & 7 \\
4 & 1 & 8 \\
4 & 2 & 3 \\
4 & 3 & 1\end{array}$ & $\begin{array}{r}7.14 \\
5.45 \\
4.00 \\
- \\
- \\
3.52 \\
5.90 \\
4.47 \\
4.13 \\
10.71 \\
1.67 \\
3.89 \\
0.83 \\
1.77 \\
2.39 \\
2.12 \\
1.42 \\
3.03 \\
1.10\end{array}$ & $\begin{array}{l}0.520 \\
0.580 \\
0.490 \\
0.571 \\
0.325 \\
0.473 \\
0.361 \\
0.490 \\
0.559 \\
0.816 \\
0.283 \\
0.495 \\
0.315 \\
0.315 \\
0.303 \\
0.409 \\
0.329 \\
0.216 \\
0.412 \\
0.295\end{array}$ \\
\hline
\end{tabular}

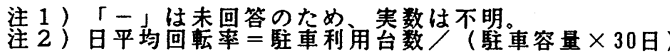

各駐車場の駐車容量は、表－ 5 に示す様に大きく 差があるが、日平均回転率（駐車利用台数／(駐車 容量×30日））と選好得点の間には、図-4のよ 
うに、指数曲線で表される相関関係が見いだせた。 この結果の関係を用いて、駐車場利用台数予測モ デルを推定すると、次の関数式で表すことができる。

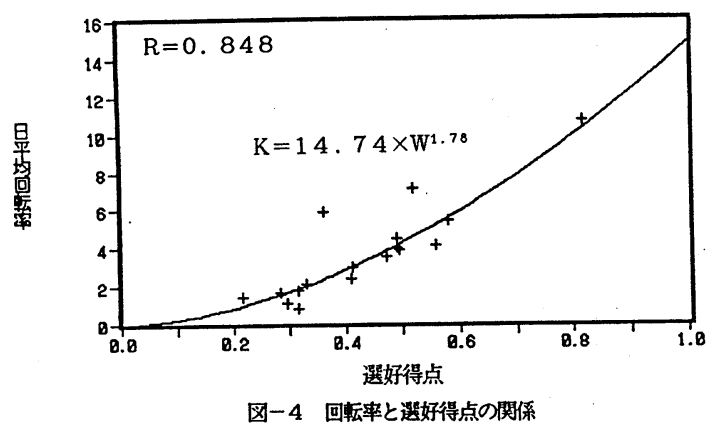

〈駐車場利用台数予測モデル>

$$
\begin{aligned}
& \mathrm{K}=14.74 \times \mathrm{W}^{1.78} \\
& \mathrm{~T}=30 \times \mathrm{K} \times \mathrm{C}
\end{aligned}
$$

ゆえに、

$$
\mathrm{T}=442.2 \times \mathrm{W}^{1.78} \times \mathrm{C}
$$

ここで、 $\mathrm{T}:$ 駐車場利用台数（1力月当たり）

$\mathrm{K}$ : 駐車場における日平均回転率

$\mathrm{W}:$ 駐車場の選好得点

C : 駐車場の駐車容量

次に、この予測モデル式に駐車場の選好得点及び 駐車容量を代入して、駐車場の推定利用台数を算出 し、実測値と比較したものが図ー 5 であり、0.959 いう高い相関係数が得られた。

この結果により、意識調查による選好得点と駐車 場の利用行動が、間接的とはいえ密接な相関関係に あることが実証できたことになる。

ただし、この予測モデル式は、駐車場の需要・供 給関係を表す回転率が一定という仮定のもとで成立 するすのであり、簡単で実用性は高いが、その使い 方には注意が必要である。

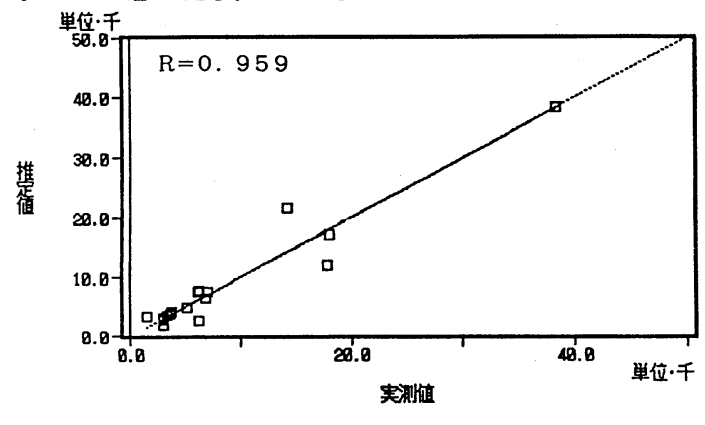

冈-5 実測値と推定値の比較

\section{（2）新規駐車場の需要予測}

構筑できた予測モデルを用いて、長岡市の大手通 りの地下に新たに建設が予定されている地下駐車場 の需要予測を行ってみた。

分析においては、現時点で想定される整備・運営 計画に合わせたすのを、基本ヶース（表一 6 のケー ス 5 ) とする。

駐車場の位置は大手通りの地下、容量は 200 台、 形態は自走・立体式、料金は 320 円 $/ \mathrm{h}$ 、買物割 引あり、標識あり、待ち時間 5 分程度と設定した。

駐車容量 200 台という条件は、中心商業地にお ける駐車需給均衡を変化させ、回転率が減少する可 能性を持っているが、今回は回転率一定と仮定する。 感度分析を行うために、駐車容量及び駐車形態 （自走・立体式）は固定して、駐車料金、買物割引 の有無、待ち時間の水準值を変化させ、選好得点の 変化と駐車台数への影響をみる 11 ケースを加えて、 計 12 ケースについて駐車利用台数を算出した。

\begin{tabular}{|c|c|c|c|c|c|c|}
\hline \multirow{2}{*}{ 地下駐車場 } & \multicolumn{3}{|c|}{ 変化項目 } & \multicolumn{3}{|c|}{ 感度分析 } \\
\hline & $\begin{array}{l}\text { 駐車 } \\
\text { 料金 }\end{array}$ & $\begin{array}{l}\text { 買物 } \\
\text { 割引 }\end{array}$ & $\begin{array}{l}\text { 待ち } \\
\text { 時間 }\end{array}$ & $\begin{array}{l}\text { 選好 } \\
\text { 得点 }\end{array}$ & $\begin{array}{l}\text { 駐車利用台 } \\
\text { 数 (台 } / \text { 月) }\end{array}$ & $\begin{array}{c}\text { 変化率 } \\
(\%)\end{array}$ \\
\hline ケース 1 & 200円 & 0 & 0 & 0.566 & 32,056 & +119.2 \\
\hline ケース 2 & $320 \mathrm{P}$ & $\bigcirc$ & $\bigcirc$ & 0.483 & 24,180 & +65.4 \\
\hline ケース 3 & $400 \mathrm{H}$ & 0 & 0 & 0.464 & 22,521 & +54.0 \\
\hline ケース 4 & 200円 & 0 & $x$ & 0.447 & 21,062 & +44.0 \\
\hline $3-85$ & $320 \mathrm{M}$ & 0 & $x$ & 0365 & 14622 & मे \\
\hline ケース 6 & $400 \mathrm{~m}$ & 0 & $x$ & 0.346 & 13,298 & -9.1 \\
\hline ケース 7 & $200 円$ & $\times$ & 0 & 0.450 & 21,274 & +45.5 \\
\hline ケース 8 & $320 円$ & $\times$ & 0 & 0.367 & 14,803 & +1.2 \\
\hline ケース 9 & 400円 & $x$ & 0 & 0.348 & 13,472 & -7.9 \\
\hline ケース10 & $200 \mathrm{~m}$ & $\times$ & $x$ & 0.331 & 12,313 & -15.8 \\
\hline ケース11 & 320 円 & $x$ & $x$ & 0.248 & 7,371 & -49.6 \\
\hline ケース12 & $400 円$ & $\times$ & $x$ & 0.229 & 6,401 & -56.2 \\
\hline
\end{tabular}
その結果を、表一 6 に示す。

\section{表一6 変化項目の組み合わせ及び感度分析}

注1）買物㓶引において、O：あり、X：なし

注2) 駐車待ち時間において、 $O$ :なし、 $\times: 5$ 分程度 注3) 棢掛けは基本ケースのケース

予測結果から、基本ヶースの地下駐車場は、1ヶ 月当たり約14,600台の利用台数が見込まれる。

水準の変化による台数の変化は、駐車料金を 320 円から200円にした場合、約 $45 \%$ ：6,500台の増加（ケ 一ス4)、駐車料金を 320 円から 400 円にした場合、 約10\%: 1,300台の減少（ケース6）、買物割引をあ りからなしにした場合、約50\%：7,300台の減少（ケ ース 1 1)、待ち時間を 5 分程度からなしにした場 合、約 $65 \%: 10,000$ 台の増加（ケース2）、という結 果が得られた。 
このように、利便性、経済性に関する要因を変化 させると、駐車利用台数が著しく変化することが明 かとなった。

本モデルによって、駐車場整備・運営に関する政 策決定に際し、各要因を変化させた場合の影響を予 測することができると考えられる。

\section{6.おわりに}

本研究は、地方都市の中心商業地における駐車場 の選好について、利用者の意識調查をるとに「利用 者の利便性」という視点から探り、それらと駐車場 整備との関係を分析することにより、駐車需要予測 モデルを構築し、新規駐車場の整備の影響を検討し たすのである。

結論をまとめると、以下の通りである。

（1）駐車場選好の意識構造を把握するため、A H P とC J Mの 2 種類の手法を適用したが、A H P 手 法による解析の方が、操作性と信頼性の点で優れて いた。

（2）駐車場利用者（買物客）は、利便性を表す 「目的地までの距離」と「駐車待ち時間」、及び経 済性に関連する「駐車料金」、「買物割引の有無」 を特に重要視している。

（3）駐車場選好と回転率との関係より、駐車場需 要予测モデルを構筑した。そのモデルを用いた新規 駐車場の需要予測及び感度分析を行い、回転率一定 という仮定のもとで、利便性と経済性の要因により 駐車場利用台数が著しく変化することが判明した。

今後の研究課題として、以下のことがあげられる。 すなわち、今回構築した駐車需要予测モデルは、回 転率一定という仮定を立てている。

そこで、新規駐車場の整備による既存駐車場への 影響、あるいは、潜在的な需要す含めた全体として の駐車需要変化を考察することができる様なモデル の開発が必要があろう。

平成 7 年度に予定される地下駐車場の完成後の実 態調查等を踏まえ、さらに適用性の高い需要予測モ デルを構筑し、駐車場整備・運営の施策に寄与する ことが課題である。

最後に、調查に協力いただいた各駐車場管理者の
方々及びアンケートを記入いただいた皆様並びに C J Mに関し種々ご指導睗った長岡高専湯沢昭助教授 に感謝申し上げます。

\section{【参考文献】}

1) 新谷洋二 : 駐車対策の経緯と駐車場整備推進の 課題、都市と交通 No. 3、PP. 7-11、1988

2 ）原田昇、浅野光行 : 駐車場選択を考慮した都心 部と郊外 S C の競合モデルに関する研究、土木計画 学研究・論文集 No. 7、PP.147-154、1989

3) 吉田朗、原田昇 : 混雜度を考慮した駐車利用均 衡モデルの研究、都市計画学術研究論文集 No. 24、 PP271-276、1989

4 ) 矢嶋宏光、屋井鉄雄、森地茂: 商業地域におけ 駐車場施設整備のための基礎的研究、土木計画学研 究・講演集 No.12、PP. 349-356、1989

5 ）塚口博司、鄭憲永 : 都心地区における駐車場選 択行動に関する一考察、都市計画学術研究論文集 $\mathrm{N}$ o. 23、PP. 397-402、1988

6 ）塚口博司、小林雅文、飯田恭敬：路上駐車を含 めた駐車場所選択特性、土木計画学研究・講演集 N o. 14、PP. 147-152、1991

7 ) 利根薰 : ゲーム感覚意志決定法、日科技研、19 86

8 ) 木下栄蔵：階層分析法による交通経路選択特性 の評価、運輸之経済 第46巻第6号、1986

9 ）中西正雄: 消費者行動分析のニューフロンティ ア、誠文堂新光社、1984

10 ）高田一尚、湯沢昭 : コンジョイント分析によ る個人行動モデルに関する研究、土木計画学研究・ 講演集 No. 11、PP. 707-714、1988

11 ）湯沢昭、須田熙、高田一尚、境潔 : コンジョ イント分析の適用性に関する実証的研究、土木計画 学研究・論文集 No.8、PP. 257-264、1990

12 ) 伊藤卓、湯沢昭、須田熙: コンジョイントロ ジットモデルにおける分解深さ決定に関する一考察、 土木学会第45回年次学術講演会、PP. 32-33、1990 